\title{
Bibliografia Russa Traduzida No Brasil (1900-1950) Breves Notas Complementares
}

\section{Denise Bottmann ${ }^{1}$}

\author{
Abstract: \\ This article discusses the Russian literature translated in Brazil between 1900 and 1950 . \\ Keywords: Russian Literature; Translation; reception.
}

\section{Fúlvio Abramo e Victor Ragghianti}

No número 14 de Tradução em Revista (2013), encontra-se um artigo meu chamado "Georges Selzoff, uma crônica". Trata-se de uma reconstituição da carreira de editor e tradutor do imigrante russo Iúri Zéltzov, com seu nome afrancesado para Georges Selzoff, que teve o importante papel de inaugurar a publicação no Brasil, em formato livro, de obras traduzidas diretamente do russo. Alguns dados bibliográficos constantes nesse artigo foram utilizados em meu levantamento "Bibliografia Russa Traduzida no Brasil (1900-1950)", publicado em RUS 4 (2014). Assim, as retificações feitas abaixo aplicam-se também aos dados respectivos constantes no referido levantamento.

O editor-tradutor Georges Selzoff, em suas traduções, sempre trabalhou com um colaborador para dar acabamento a seus textos. Nos primeiros meses de existência da Edição Cultura, empresa em sociedade com Francisco Olandim, saíram três coletâneas de contos: Konovaloff, de Górki (1930), Os inimigos e Pavilhão no. 6, ambos de Tchecov (1931). Em minha crônica de 2013, baseando-me numa mensagem de Guilherme de Almeida a saudar a iniciativa da casa, inferi erroneamente que nessa fase inicial o parceiro tradutor era o sócio editor Francisco Olandim.

Na verdade, o colaborador inicial de Selzoff, nas três primeiras obras lançadas pela então G. Selzoff \& F. Olandim, foi Fúlvio Abramo, juntamente com seu amigo Victor Ragghianti. Assim atesta uma matéria no jornal paulista A Gazeta, em 20 de junho de 1961, informando: "Fulvio Abramo e Victor Ragghianti encarregaram-se dos volumes Konovaloff, de Maximo Gorki, Os Inimigos e O pavilhão de Anton Tchecoff”.

\footnotetext{
${ }^{1}$ Mestre, docente IFCH/UNICAMP (1983-1998), historiadora e tradutora. dbottmann@gmail.com.
} 
E é o que nos informa o próprio Selzoff, em entrevista ao mesmo jornal, em 01 de agosto de 1962:

Travei relações de amizade com Fulvio Abramo, rapaz de espírito inquieto e brilhante. Falei-lhe do assunto. E ele prontificou-se a colaborar comigo no sentido de lançar autores russos em português. Indicando outro parceiro para a labuta, o talentoso jovem Vítor Ragghianti, empreendemos as primeiras traduções.

Tibiriçá (1972) retoma a informação, descrevendo o processo colaborativo do qual "surgiram os três trabalhos" acima citados.

Ainda na referida crônica, dizia eu: "No final de 1931 ou, no máximo, em janeiro de 1932, a Bibliotheca de Auctores Russos lança um volume de Leonide Andreieff, Os sete enforcados" (Bottmann, 2013). E na "Bibliografia Russa" dei o ano de 1931 (Bottmann, 2014). Aqui, graças à nota da Folha da Manhã, de 3 de janeiro de 1932, podemos precisar melhor a data. Cito: “O famoso livro, numa versão de Georges Selzoff e de Orígenes Lessa, estará nas livrarias nestes próximos dias". Considere-se o ano de 1932, portanto, como a data correta de lançamento de Os sete enforcados.

Com isso, teremos o catálogo da Bibliotheca de Auctores Russos retificado da seguinte maneira: ${ }^{2}$

· Maximo Gorki, Konovaloff, contendo "Konovaloff”, “A feira”, "Kirilka” e "Uma vez, no outomno". [Tradução GS, Fúlvio Abramo e Victor Ragghianti.] 1930. 156 p. 2a edição revista em 1931.

- Anton Tchecoff, Os inimigos, contendo "Os inimigos", "Delírio (Gussieff)", "Algazarra em família", "No carro (O caminho da mestra escola)", "Verotchka", "Estudante", "Lenda sueca (O conto do jardineiro chefe)", "Zinotchka" e "Uma noite atroz”. [Tradução GS, Fúlvio Abramo e Victor Ragghianti.] 1930. 178 p. 2a. edição revista em 1931.

- Anton Tchecoff, O pavilhão no. 6, contendo "O pavilhão no. 6", "A desgraça", "A felicidade", "A obra de arte" e "Os simuladores". [Tradução GS, Fúlvio Abramo e Victor Ragghianti.] 1930[1]. Vinhetas e illustrações de M. Barychnikoff. 187 p.

- Leon Tolstoi, Khadji-Murat. [Tradução com Allyrio Meira Wanderley.]. Obra Posthuma, Versão Integral. 1931. Vinhetas e illustrações de M. Barychnikoff. 173 p.

\footnotetext{
${ }^{2}$ Nos casos em que as edições não traziam os créditos de tradução, os dados vêm entre colchetes. Nos demais, os créditos estão reproduzidos conforme constam na página de rosto das obras.
} 
- Leon Tolstoi, Padre Sergio. [Tradução com Allyrio Meira Wanderley.] Vinhetas e illustrações de M. Barychnikoff. 1931. 176 p.

- Feodor Dostoievski, Um jogador (das notas de um rapaz). Igrok. [Tradução GS e Allyrio Meira Wanderley.] 1931. 170 p.

- Leonide Andreieff, Judas Iscariotes. [Tradução GS e Allyrio Meira Wanderley.] Illustrações de M. Barychnikoff. 1931. 141 p.

- Leonide Andreieff, Os sete enforcados. Traducção integral do original russo por Georges Selzoff e Orígenes Lessa. 1932. 150 p.

- Ivan Turguenieff, Ninho de fidalgos. Traducção integral do original russo por Elsie Lessa e Georges Selzoff. Imagem de Turguenieff por Miguel Barychnicoff.

No testo 5 illustrações e vinhetas, em nankin, feitas especialmente para esta edição, por Inne Zueff (Milão). 1932. 184 p.

- Ivan Turguenieff, Águas da primavera. Traducção integral do original russo por Brito Broca e Georges Selzoff. 1932. 201 p.

\section{Leôncio Basbaum}

$\mathrm{Na}$ relação de obras de Dostoiévski constante na "Bibliografia Russa" (Bottmann, 2014), temos a seguinte ocorrência:

Os irmãos Karamazoff. Trad. Raul Rizinsky. Collecção de Obras Celebres. Rio de Janeiro: Americana, 1931. 


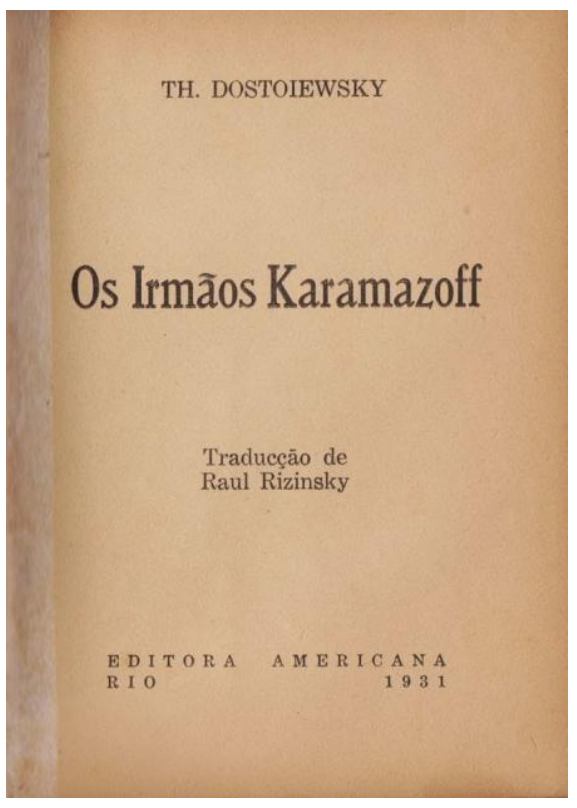

Além do ar bastante implausível do nome "Raul Rizinsky", a única referência que se encontra a seu respeito é o próprio crédito de tradução dessa obra; com suas ressonâncias russas "combinando" - de maneira um tanto forçada - com o autor e a língua original da obra, trata-se visivelmente de um nome de fantasia. Não foi a primeira nem a última vez que isso aconteceu na história editorial brasileira. Já em 1930, a mesma Americana havia lançado mão de um recurso similar na tradução de Crime e castigo, apontando como tradutor outra figura desconhecida de nome igualmente implausível, Ivan Petrovitch.

Mas um relato de Leôncio Basbaum em seu livro de memórias, Uma vida em seis tempos, esclarece o mistério referente aos Irmãos Karamázov. É tão vívido em sua descrição que merece ser reproduzido extensamente:

Para conseguir trabalho, por sugestão do antigo colega e companheiro de infância (Elias Davidovitch), fui procurar a Editora Guanabara, onde me ofereci para fazer traduções, indústria recém-começando no Brasil. Recebeu-me bem e me disse que tinha precisamente um livro a traduzir: Os irmãos Karamazov, de Dostoievsky, livro que eu conhecia e amava. Combinamos o preço, deu-me um pequeno adiantamento e em seguida me entregou o original: uma tradução francesa. Antes, porém, abriu-o pelo meio, arrancou cerca de 40 ou 50 páginas de um golpe e me disse com um ar sério: o livro é muito grosso.

Como eu me mostrasse surpreso, e um tanto escandalizado, ele explicou: o livro é muito grosso e fica muito caro. Além disso, ele fará parte de uma série de livros que são muito finos. Finalmente, o trecho certamente não tinha muita importância, e o leitor nem notaria.

- Mas, disse eu, aqui você cortou uma frase no meio e também uma palavra ficou pela metade... 
- Não tem importância, você completa a palavra e faz algumas linhas ligando um trecho com o outro...

E assim foi que me tornei colaborador e parceiro de Dostoievsky. (Basbaum, apud Silva-Reis, 2012)

Leôncio se refere aqui à editora Guanabara, não à Americana. Ocorre que desde 1931 o catálogo literário da Americana passou a fazer parte da Waissman, Reis \& Cia., que pouco depois vem a adquirir a Guanabara, adotando-lhe o nome ou usando também o nome de Guanabara Koogan (e dessa forma a Collecção de Obras Celebres da Americana se transfere para a Guanabara). Elias Davidovitch, o amigo e companheiro citado por Leôncio Basbaum, desde 1930 fazia traduções para a Americana, bem como para a posterior Guanabara. Assim, suponho que Leôncio Basbaum, em suas memórias quarenta anos mais tarde, referiu-se à editora pelo nome que, entre uma e outra fusão editorial, ela veio a adotar pouco tempo depois e que mantém até a data de hoje.

Concluindo, nosso registro de tal ocorrência bibliográfica pode ser complementado da seguinte maneira:

Os irmãos Karamazoff. Trad. Raul Rizinsky (pseud.. de Leôncio Basbaum). Collecção de Obras Celebres. Rio de Janeiro: Americana, 1931.

\section{Referências bibliográficas}

Bottmann, Denise. "Bibliografia russa traduzida no Brasil (1900-1950). In: RUS 4, 2014, 58-87.

http://www.usp.br/rus/images/edicoes/Rus_n04/05\%20bibliografia\%20russa\%20traduzi da\%201900-1950.pdf

. “Georges Selzoff, uma crônica”. In: Tradução em Revista 14, 2013/1, 208-229.

http://www.maxwell.lambda.ele.puc-rio.br/trad_em_revista.php?strSecao=input0

Na Sementeira Editorial dos Livros. In: A Gazeta, 20/06/1961.

Palavras do Antigo Tradutor Georges Selzoff. In: A Gazeta, 01/08/1962.

Livros Novos. In: Folha da Manhã, 03 de janeiro de 1932.

Silva-Reis, Dennys da. “O romance hugoano L'Homme qui rit". In: Arena Romanistica $10,2012$.

Tibiriçá, Everardo. “O Tradutor Georges Selzoff”. In: Diário Popular, 16/01/1972. 


\section{Agradecimentos}

Tais retificações e complementações sobre a Bibliotheca de Auctores Russos não teriam sido possíveis sem a generosa contribuição do historiador Dainis Karepovs, que me encaminhou cópias das matérias publicadas nos jornais A Gazeta e Diário Popular, e o amoroso apoio de Federico Carotti, que me encaminhou ao acervo da Folha. A Alex Quintas de Souza agradeço a imagem da página de rosto de Os Irmãos Karamazoff. 